\title{
PENGUASAAN TANAH DI INDONESIA OLEH WARGA NEGARA ASING MELALUI PERKAWINAN CAMPURAN DALAM FALSAFAH HUKUM
}

\author{
Indah Jacinda, Jason Jusuf, Verlin Ferdina \\ Fakultas Hukum Universitas Tarumanagara
}

\begin{abstract}
ABSTRAK
Kombinasi perkembangan teknologi informasi dan komunikasi dan internet, menyebabkan seseorang dapat dengan mudah berkomunikasi secara global dengan orang lain. Ini memungkinkan seseorang dapat menjalin hubungan, dan terikat dalam pernikahan. Dengan adanya perkawinan campuran di Indonesia, hal itu mempengaruhi kepemilikan harta masyarakat dalam perkawinan. Harta bersama dalam pernikahan juga dapat mengambil bentuk kepemilikan objek tertentu. Salah satunya adalah Hak Milik yang merupakan hak paling kuat dan melekat yang dapat dimiliki atas tanah di Indonesia. Namun, banyak kasus muncul terkait status kepemilikan hak atas tanah yang diperoleh orang asing melalui pencampuran aset perkawinan dalam pernikahan antar Warga Negara Indonesia. Oleh karena itu jurnal penelitian ini dimaksudkan untuk meneliti lebih lanjut status kepemilikan hak atas tanah di Indonesia yang dimiliki oleh orang asing melalui perkawinan campuran.
\end{abstract}

Kata Kunci: Perkawinan Campuran, Harta Bersama, Hak Milik.

\begin{abstract}
Simultaneous developments in information and communication technology and the internet, make everyone easily communicate globally with other person. This makes it possible that a person can establish a relationship and get married. With the existence of intermarriages in Indonesia, it affects the ownership of community property in marriage. Community property in marriage can also take the form of ownership of certain objects. One of them is the rights of ownership which is the strongest and fullest right one can have on land in Indonesia. However, many cases arise regarding the status of ownership of land rights obtained by foreigners through the mixing of marital assets in intermarriages with Indonesian citizens. Therefore, this research aims to examine the ownership status of land rights in Indonesia owned by foreigners through intermarriages.
\end{abstract}

Keywords: intermarriages, community Property, the Rights of Ownership. 


\section{PENDAHULUAN}

Pada era globalisasi yang serba modern saat ini, perkembangan teknologi sangat berkembang dengan pesat. Terutama pada teknologi informasi dan komunikasi. Teknologi informasi dan komunikasi dapat diartikan sebagai:1)

"we may define Information and Communication Technology as one of the driving forces of globalization ICT encompasses the broad spectrum of communication technologies from radio, film, television, press, and telephone along with more participatory forms such as theatre, video or story telling. It also focuses on the electronic end of the spectrum such as e-mail, the Internet, mobile phones and digital video".

Manfaat dari perkembangan teknologi informasi dan komunikasi saat ini dapat dirasakan dalam memenuhi kebutuhan sehari-hari. Salah satu manfaat dengan adanya perkembangan teknologi informasi dan komunikasi pada era globalisasi ini yaitu batas-batas negara seakan terasa hilang. Artinya, orang dengan mudah untuk melakukan komunikasi dengan orang lain tanpa terbatas oleh wilayah dan waktu. Seseorang dalam suatu negara dapat berkomunikasi dengan mudah dengan orang lain yang berada di belahan dunia yang berbeda pada waktu yang sama. Hal tersebut didukung juga dengan adanya teknologi jaringan global (cyberspace) atau yang dikenal dengan internet.

Dengan gabungan dari kemajuan teknologi informasi dan komunikasi dan internet, seseorang dengan mudah untuk melakukan komunikasi secara global. Hal tersebut tidak menutup kemungkinan bahwa seseorang dapat menjalin suatu hubungan, dan terikat dalam suatu perkawinan. Faktor tersebutlah yang menyebabkan adanya perkawinan campuran. Perkawinan campuran dapat didefinisikan sebagai, "interracial relationships are defined in terms of race, critical race theory, centrally focused on the inherent Black/White binary in American society". 2

Perkawinan campuran juga terjadi di Indonesia, istilah perkawinan campuran di Indonesia yang sering dinyatakan anggota masyarakat sehari-hari,

${ }^{1}$ Bayo Idowu et al., "Information and Communication Technology in Nigeria The Health Sector Experience", Journal of Information Technology Impact, Volume 3 No. 2 Tahun 2018, hal.69

${ }^{2}$ Catherine A. Luther and Jodi L. Rightler-McDaniels, "More Trouble than the Good Lord Ever Intended: Representations of Interracial Marriage in U.S. News-Oriented Magazines", Journal of Magazine \& New Media Research, Volume 4 No. 1 Tahun 2013, hal.3 
ialah perkawinan campuran karena perbedaan adat atau suku bangsa yang bhinneka, atau karena perbedaan agama antara kedua insan yang akan melakukan perkawinan. Perbedaan adat misalnya perkawinan antara pria/wanita Minangkabau dengan pria/wanita Sunda. Sedangkan perkawinan campuran antar agama, misalnya antara pria/wanita beragama Kristen dengan pria/wanita beragama Islam, dan sebagainya. ${ }^{3}$

Perkawinan Campuran di Indonesia diatur lebih lanjut dalam Pasal 57 Undang - Undang Nomor 1 Tahun 1974 Tentang Perkawinan (yang selanjutnya disebut dengan UU Perkawinan) yaitu, "yang dimaksud dengan perkawinan campuran dalam Undang-Undang ini ialah perkawinan antara dua orang yang di Indonesia tunduk pada hukum yang berlainan, karena perbedaan kewarganegaraan dan salah satu pihak berkewarganegaraan Indonesia"

Dengan adanya perkawinan campuran di Indonesia, berpengaruh terhadap kepemilikan harta bersama dalam perkawinan. Harta bersama dalam perkawinan menurut Pasal 35 UU Perkawinan didefinisikan sebagai "Harta benda yang diperoleh selama perkawinan menjadi harta bersama; Harta bawaan dari masingmasing suami dan isteri dan harta benda yang diperoleh masing-masing sebagai hadiah atau warisan, adalah di bawah penguasaan masing-masing sepanjang para pihak tidak menentukan lain.”. Harta bersama dalam perkawinan juga dapat berupa penguasan hak milik pada objek tertentu. Penguasaan hak milik yang paling sering menjadi objek yaitu hak milik atas tanah.

Penguasaan Hak Milik atas tanah pada hakikatnya didefiniskan oleh Curzon dengan Hak Milik dengan property yakni: ${ }^{4}$

"The following are examples of many definitions of "property" : The highest right men have to anything"; "a right over a determinate thing either a tract of land or chattel"; "an exclusive right to control an economic good"; "an aggregate of rights guaranteed and protected by the government"; "everything which is the subject of ownership"; "a social institution whereby people regulate the acquisition and use of the resources of our environment according to a system of rules"; "a concept that refers to the rights,

\footnotetext{
${ }^{3}$ Hilman Hadikusuma, Hukum Perkawinan Indonesia Menurut Perundangan, Hukum Adat, Hukum Agama, Cetakan ke-3, (Bandung: Mandar Maju, 2007), hal.13

${ }^{4}$ L.B. Curzon, Land Law, Seventh Edition, (Great Britain: Pearson Education Limited, 1999), hal. 8-9.
} 
obligations, privileges and restrictions that govern the relations of men with respect to thins of value."

Sedangkan Hak Milik atas tanah di Indonesia diatur dalam Undang-Undang Nomor 5 Tahun 1960 Tentang Peraturan Dasar Pokok-Pokok Agraria (yang selanjutnya disebut dengan UUPA). ${ }^{5}$ Secara khusus diatur dalam Pasal 20 Ayat 1 UUPA, "Hak milik adalah hak turun-temurun, terkuat dan terpenuh yang dapat dipunyai orang atas tanah, dengan mengingat ketentuan dalam Pasal 6.”

Namun, banyak kasus yang timbul perihal status penguasaan hak milik atas tanah yang diperoleh warga negara asing melalui percampuran harta perkawinan dalam perkawinan campuran dengan warga negara Indonesia. Salah satu contoh kasusnya yaitu terjadi di Kecamatan Ruteng Kabupaten Manggarai-Flores di Menjerite, Manggarai Barat pada tahun 2017, yakni Robert seorang warga negara Australia yang mengaku memiliki hak atas tanah, dimana tanah itu dimiliki atas nama Fauziah yang merupakan warga negara Indonesia suku Bugis. Robert mengatakan bahwa Fauziah adalah istrinya namun ia tidak menyebutkan kapan mereka menikah dan Robert tetap mengakui bahwa tanah tersebut adalah tanah miliknya. ${ }^{6}$

Berdasarkan uraian latar belakang yang dikemukakan sebelumnya, maka Penulis merasa tertarik untuk mengkaji mengenai topik tersebut secara komprehensif dengan analisa yang bersifat falsafi. Penulis juga dapat lebih mendalami, mengerti, dan menghayati dengan sebenar-benarnya dan setepattepatnya dan menuangkannya dalam bentuk jurnal dengan judul "Penguasaan Tanah Di Indonesia Oleh Warga Negara Asing Melalui Perkawinan Campuran Dalam Falsafah Hukum”. Karena faktanya banyak kejanggalan dan ketidakpastian hukum dari akibat hubungan hukum tersebut. Di mana dari fakta yang ada, sering kali menimbulkan kerancuan perihal status penguasaan hak milik atas tanah yang telah ada di Indonesia.

${ }^{5}$ Urip Santoso, Perolehan Hak Atas Tanah, Cetakan ke-1, (Jakarta: Prenada Media, 2015), hal. 37

${ }^{6}$ Anonim, "Kasus Menjerite Ungkap Modus Kepemilikan Tanah WNA di Mabar", http://www.floresa.co/2017/01/17/kasus-menjerite-ungkap-modus-kepemilikan-tanah-wna-dimabar/, 1 September 2018. 


\section{PERMASALAHAN}

Bagaimana status kepemilikan hak atas tanah di Indonesia yang dimiliki oleh warga negara asing melalui perkawinan campuran?

\section{PEMBAHASAN}

1. Teori Perubahan Sosial (Auguste Comte)

Adanya perubahan sosial di dalam kehidupan manusia telah disampaikan oleh Auguste Comte. Auguste Comte berpendapat pengaruh terbesar datang dari evolusi intelektual. Dalam pandangan positivisme, Comte kemudian berpendapat bahwa manusia itu mengalami evolusi atau mengalami tahap kemajuan dalam berpikir. Comte, kemudian merumuskan perkembangan manusia menjadi 3 tahap atau jenjang. ${ }^{7)}$

\section{A. Tahap Teologis}

Tahap ini merupakan periode terlama dalam sejarah. Karena awal mula perkembangan akal budi memakai gagasan keagamaan yang belum adanya penguasaan atas makhluk lain. Tahap ini pun dibagi menjadi tiga periode :

a. Periode Fetisisme

Bentuk pemikiran masyarakat primitif kepercayaan atas roh-roh atau bangsa halus yang turut hidup bersama kita. Ini terlihat pada zaman purba dimana diadakan upacara penyembahan roh halus untuk meminta bantuan maupun perlindungan.

b. Periode Politeisme

Periode ini masyarakat telah percaya akan bentuk para penguasa bumi yakni para dewa-dewa yang terus mengontrol semua gejala alam.

c. Periode Monoteisme

Semakin majunya pemikiran manusia, pada periode terakhir ini muncul kepercayaan akan satu yang tinggi pada abad pertengahan. Kepercayaan akan Tuhan yang berkuasa penuh atas jagad raya, mengatur segala gejala alam dan takdir makhluk.

\section{B. Tahap Metafisik}

Tahap transisi dari teologi ke tahap positif. Dimana segala gejala sosial terdapat kekuatan yang dapat terungkapkan (ditemukan dengan akal budi).

${ }^{7}$ Soerjono Soekanto, Teori Sosiologi Tentang Perubahan Sosial, Cetakan ke-2, (Jakarta: Ghalia Indonesia, 1984), hal.61 
Namun disini belum adanya verifikasi. Meskipun penerangan dari alam sendiri tapi belum berpangkal pada data empiris. Jadi, bisa dikatakan masih pergeseran cara berpikir manusia.

C. Tahap Positif

Di tahap ini gejala alam dijelaskan secara empiris namun tidak mutlak. Tapi pengetahuan dapat berubah dan mengalami perbaikan seiring intelektual manusia sehingga dapat diterapkan dan dimanfaatkan. Akal budi penting tapi harus berdasarkan data empiris agar memperoleh hukum-hukum baru.

Dari teori ini dapat terlihat bahwa dengan adanya evolusi intelektual atau perkembangan pemikiran ini menyebabkan adanya perubahan sosial antara hubungan manusia dengan manusia lainnya di dalam masyarakat. Pada awalnya pemikiran seorang manusia hanya sebatas pemikiran teologis yakni pemikiran akal budi manusia mengenai adanya suatu kepercayaan, manusia lebih mengutamakan hidupnya untuk berinteraksi kepada roh atau dewa menurut kepercayaannya pada masa itu, sedangkan interaksi dengan manusia lainnya hanya dilakukan untuk memenuhi kebutuhan primernya. Selanjutnya pemikiran manusia mulai berkembang ke arah yang sifatnya positivisme dimana manusia sangat bergantung kepada sesamanya dalam memenuhi kebutuhannya baik primer maupun sekunder.

Dengan adanya sifat pemikiran yang positivisme ini dan didukung dengan adanya perkembangan informasi dan teknologi yang sangat pesat, memicu manusia untuk melakukan interaksi dengan manusia lainnya walaupun adanya perbedaan jarak dan waktu. Sebagai contoh interaksi manusia yang dilakukan melalui media sosial ataupun smartphone, hal ini memungkinkan seseorang di suatu negara dapat menjalin hubungan dengan orang yang berada di negara lain yang pada zaman ini dianggap menjadi suatu hal yang lumrah.

Selanjutnya, hal ini jugalah yang menyebabkan perkawinan campuran sering terjadi di Indonesia. Dengan sering adanya perkawinan campuran yang terjadi di Indonesia, menyebabkan adanya permasalahan di dalam menentukan kepemilikan atas suatu benda, terutama akan konsekuensi kepemilikan tanah di Indonesia yang muncul akibat adanya perkawinan campuran. 


\section{Pengertian dan Konsep Hak Milik}

Pengertian dan konsep hak milik menurut filsafat dapat dilihat dari pandangan-pandangan para ahli hukum yang sudah lama mengkaji tentang hak milik dalam kajian filsafat hukum. Seorang pakar hukum yang mengkaji secara khusus tentang hak milik dalam filsafat hukum adalah Roscoe Pound. Dalam bukunya beliau menyatakan "hak milik dalam arti seluas-luasnya meliputi milik yang tak berwujud (incorporeal property). Hak milik sebagai hak pangkal (originair recht) karena dengan adanya hak milik dapat terjadi hak-hak lainnya yang merupakan hak turunan (afgeleide rechten)". 8

Hak pangkal disini berkaitan dengan kekuatan hak milik dan melebihi hakhak yang lain. Hak milik sebagai suatu hak kebendaan yang diatur dalam Kitab Undang-Undang Hukum Perdata (yang selanjutnya disebut KUH Perdata) Indonesia yang berasal dari Burgerlijk Wetboek (BW) Belanda, dipahami sebagai suatu hak absolut dan merupakan hak induk serta merupakan sumber dari pemilikan seperti dalam pasal 570 KUH Perdata. Hak untuk membuat suatu benda menguasai sepenuhnya dan untuk menguasai benda itu sebebas-bebasnya asal tidak bertentangan dengan Undang-undang. Dari konsep hukum perdata, maka hak milik terfokus pada penguasaan suatu benda dan hubungan hukum orang dengan suatu benda. Kepemilikan selalu dikaitkan dengan kekuasaan, yang menjadi pemilik dan yang mampu menguasai dan mempergunakan benda itu. ${ }^{9)}$

Dari hak milik tersebut maka munculah berbagai hak yang melekat dan meliputi misalnya, kepemilikan atas suatu benda menyebabkan memungkinkannya seseorang untuk mempergunakan dan menikmati hak atas benda tersebut. Dengan demikian hak milik dapat dikatakan sebagai hak kebendaan yang paling utama apabila dibandingkan dengan hak kebendaan yang lain. Adapun ciri-ciri hak milik menurut Prof. Sri Soedewi Masjchoen Sofwan adalah: ${ }^{10}$

\footnotetext{
${ }^{8}$ Roscoe Pound, Pengantar Filsafat Hukum, (Jakarta: Bhratara Niaga Media, 1989), hal. 118

${ }^{9}$ Jemmy Sondakh, "Hak Milik atas Tanah Menurut Hukum Adat", E-Journal Universitas Sam Ratulangi, 2014, hal. 7 2000), Hal. 48

${ }^{10}$ Sri Soedewi Masjchoen Sofwan, Hukum Perdata: Hukum Benda, (Yogyakarta: Liberty,
} 
1. Hak milik merupakan hak induk terhadap hak kebendaan lainnya;

2. Hak milik merupakan hak yang selengkap-lengkapnya;

3. Hak milik bersifat tetap, artinya tidak akan lenyap terhadap hak kebendaan yang lain;

4. Hak milik merupakan inti dari kebendaan yang lain.

Meskipun hak milik merupakan hak kebendaan yang utama, terhadap hak milik terdapat beberapa pembatasan, yaitu: ${ }^{11)}$

1. Undang-undang dan peraturan umum;

2. Tidak menimbulkan gangguan;

3. Kemungkinan adanya pencabutan hak (onteigening);

4. Hukum tetangga;

5. Penyalahgunaan hak.

Lalu, secara umum cara memperoleh hak milik diatur dalam Pasal 584 Kitab Undang-Undang Hukum Perdata, yaitu:

1. Pemilikan / pendakuan (toeeigening);

2. Perlekatan / ikutan (natrekking);

3. Daluwarsa / lampaunya waktu (verjaring);

4. Pewarisan (erfopvolging), baik menurut undang-undang maupun surat warisan;

5. Penunjukan / penyerahan (levering).

Dari pengertian dan konsep hak milik yang telah dipaparkan secara singkat diatas memiliki arti bahwa pada prinsipnya hak milik pribadi adalah hak yang paling penting yang dimiliki seseorang. Hak milik merupakan hak kebendaan yang utama dan terdapat pembatasan terhadap hak tersebut. Dalam KUH Perdata telah diatur mengenai cara memperoleh hak milik, dan jelas disebutkan bahwa tidak ada perolehan hak milik dikarenakan perkawinan campuran.

3. Pengaturan Hak Milik Warga Negara Asing dalam UUPA

Dalam UUPA, diatur mengenai hak atas tanah. Hak atas tanah merupakan suatu hak yang dimiliki oleh pemegang hak untuk menggunakan serta mengambil

\footnotetext{
${ }^{11}$ Ibid., Hal. 50
} 
manfaat dari tanah tersebut. ${ }^{12)}$ Dalam Pasal 16 Ayat 1 UUPA, diatur mengenai jenis-jenis hak atas tanah sebagai berikut:

“(1) Hak-hak atas tanah sebagai yang dimaksud dalam pasal 4 ayat 1 ialah : a. hak milik, b. hak guna usaha, c. hak guna bangunan, d. hak pakai, e. hak sewa, f. hak membuka tanah, g. hak memungut hasil hutan, h. hak-hak lain yang tidak termasuk dalam hak-hak tersebut diatas yang akan ditetapkan dengan undang-undang serta hak-hak yang sifatnya sementara sebagai yang disebutkan dalam pasal 53”.

Sedangkan subjek yang dapat mempunyai (subjek hak) tanah hak milik menurut UUPA dan peraturan pelaksanaanya adalah: ${ }^{13)}$

\section{Perseorangan}

Hanya warga Negara Indonesia yang dapat mempunyai Hak Milik (Pasal 21 Ayat 1 UUPA). Ketentuan ini menentukan perseorangan yang hanya berkewarganegaraan Indonesia yang dapat mempunyai tanah Hak Milik.

2. Badan-badan hukum

Pemerintah menetapkan badan-badan hukum yang dapat mempunyai Hak Milik dan syarat-syaratnya (Pasal 21 Ayat 2 UUPA).

Berdasarkan Pasal 21 Ayat 1 UUPA tersebut, maka hanya warga negara Indonesia yang dapat mempunyai hak milik atas tanah. Hak ini merupakan syarat mutlak yang harus dipenuhi untuk dapat memiliki hak milik atas tanah. Pasal 21 Ayat 1 UUPA merupakan perwujudan dari asas nasionalitas. Penerapan asas nasionalitas yang dianut UUPA dalam pemilikan hak milik atas tanah memberikan konsekuensi adanya perbedaan perlakuan antara warga negara Indonesia dengan warga negara asing. ${ }^{14)}$

Maka terhadap warga negara asing berlaku ketentuan dalam Pasal 21 Ayat 3 UUPA yaitu, "Orang asing yang sesudah berlakunya Undang-undang ini memperoleh hak milik karena pewarisan tanpa wasiat atau percampuran harta karena perkawinan, demikian pula warganegara Indonesia yang mempunyai hak milik dan setelah berlakunya undang-undang ini kehilangan kewarganegaraannya

\footnotetext{
${ }^{12}$ Kadek Rita Listyanti dan Ni Made Ari Yuliartini Griadhi, "Hak Atas Tanah Bagi Orang Asing Di Indonesia Terkait Dengan Undang-Undang No. 5 Tahun 1960”, E-Jurnal Universitas Udayana, Volume 1, Tahun 2014, hal.3

${ }^{13}$ Urip Santoso, Hukum Agraria Dan Hak - Hak Atas Tanah, cetakan ke-5, (Jakarta: Kencana Pranada Media,2009), hal.93

${ }^{14}$ Martin Roestamy, Konsep-Konsep Hukum Kepemilikan Properti Bagi Orang Asing (Dihubungkan dengan Hukum Pertanahan), (Bandung: Alumni, 2011), hal. 98
} 
wajib melepaskan hak itu dalam jangka waktu satu tahun sejak diperolehnya hak tersebut atau hilangnya kewarganegaraan itu. Jika sesudah jangka waktu tersebut lampau hak milik itu tidak dilepaskan, maka hak tersebut hapus karena hukum dan tanahnya jatuh pada negara, dengan ketentuan bahwa hak-hak pihak lain yang membebaninya tetap berlangsung."

Dari penjelasan Pasal 21 Ayat 3 UUPA, dapat dikatakan bahwa warga negara asing tidak dapat memiliki hak atas tanah. Namun apabila warga negara asing mendapatkan suatu hak milik karena suatu hak waris dan/atau perkawinan campuran dengan warga negara Indonesia setelah berlakunya UUPA, maka warga negara asing tersebut maupun warga negara indonesia yang secara bersama-sama maupun secara diri pribadi mendapatkan suatu hak milik atas tanah, harus melepaskan hak tersebut dalam jangka waktu 1 (satu) tahun sejak hak atas tanah tersebut diperoleh atau pada saat hilangnya kewarganegaraannya. Apabila dalam jangka waktu yang telah ditentukan tersebut, tetap tidak dilepaskannya hak milik atas tanah, maka hak tersebut akan hapus oleh hukum dan tanah yang menjadi objek hak milik tersebut, akan dikuasai oleh negara.

Pelepasan hak tersebut dapat dilakukan dengan cara menjualnya atau menghibahkannya, atau sesuai dengan ketentuan dalam Pasal 26 Ayat 1 UUPA yaitu, "Jual-beli, penukaran, penghibahan, pemberian dengan wasiat, pemberian menurut adat dan perbuatan-perbuatan lain yang dimaksudkan untuk memindahkan hak milik serta pengawasannya diatur dengan Peraturan Pemerintah". Hak milik dapat beralih dan dialihkan kepada pihak lain. Dialihkan atau pemindahan hak artinya beralihnya hak milik atas tanah dari pemiliknya kepada pihak lain dikarenakan adanya suatu perbuatan hukum. ${ }^{15}$

Mengenai pengaturan lebih lanjut terdapat dalam Pasal 2 Ayat 1 dan 2 Peraturan Pemerintah Nomor 103 Tahun 2015 Tentang Pemilikan Rumah Tempat Tinggal atau Hunian oleh Orang Asing yang Berkedudukan Di Indonesia (yang selanjutnya disebut PP 103/2015) dijelaskan bahwa:

“(1) Orang Asing dapat memiliki rumah untuk tempat tinggal atau hunian dengan Hak Pakai. (2) Orang Asing yang dapat memiliki rumah tempat tinggal atau hunian sebagaimana dimaksud

\footnotetext{
${ }^{15}$ Muhammad Yamin Lubis dan Abdul Rahim Lubis, Hukum Pendaftaran Tanah, (Bandung: Mandar Maju, 2010), hal.30
} 
pada ayat (1) adalah Orang Asing pemegang izin tinggal di Indonesia sesuai dengan ketentuan peraturan perundang-undangan”.

Jadi warga negara asing tidak diperbolehkan memiliki hak milik atas tanah, hanya diperbolehkan menggunakan hak pakai terhadap tanah yang digunakan sebagai tempat tinggal atau tempat usaha. Hak pakai tersebut dapat diperoleh warga negara asing sesuai dengan ketentuan Pasal 41 Ayat 2 dan 3 UUPA yaitu:

“(2) Hak pakai dapat diberikan : a. selama jangka waktu yang tertentu atau selama tanahnya dipergunakan untuk keperluan yang tertentu; b. dengan cuma-cuma, dengan pembayaran atau pemberian jasa berupa apapun.

(3) Pemberian hak pakai tidak boleh disertai syarat-syarat yang mengandung unsur-unsur pemerasan".

Hak pakai atas tanah memberikan kewenangan kepada pemegang haknya untuk memungut hasil dari tanah yang dikuasai langsung oleh negara atau tanah milik orang lain, yang memberi wewenang dan kewajiban yang ditentukan dalam keputusan pemberiannya oleh pejabat yang berwenang memberikannya atau dalam perjanjian dengan pemilik tanahnya. Sertifikat berstatus hak pakai dengan jangka waktu 30 (tiga puluh) tahun, dapat dilakukan perpanjangan waktu sampai 20 (dua puluh) tahun dan diperpanjang lagi hingga 30 (tiga puluh) tahun.

Selain hak pakai, warga negara asing juga diperbolehkan menggunakan hak sewa bangunan. Adapun hak sewa bangunan menurut Pasal 44 Ayat 1 UUPA yaitu, “(1) Seseorang atau suatu badan hukum mempunyai hak sewa atas tanah, apabila ia berhak mempergunakan tanah milik orang lain untuk keperluan bangunan, dengan membayar kepada pemiliknya sejumlah uang sebagai sewa". Hak sewa bangunan memberikan kewenangan kepada pemegang haknya untuk mempergunakan tanah hak milik orang lain untuk keperluan bangunan dengan membayar kepada pemiliknya sejumlah uang sewa.

\section{Pengaturan dalam UU Perkawinan}

Di Indonesia, perihal aturan perkawinan diatur secara khusus dalam UU Perkawinan. Ketentuan Pasal 1 UU Perkawinan, perkawinan dapat didefinisikan sebagai, "Perkawinan adalah ikatan lahir batin antara seorang pria dan seorang wanita sebagai suami istri dengan tujuan membentuk keluarga atau rumah tangga yang bahagia dan kekal berdasarkan Ketuhanan Yang Maha Esa”. Ikatan 
perkawinan dapat terjadi antara pria dan wanita yang berbeda latar belakang, termasuk latar belakang budaya dan negara.

Perkawinan yang terjadi antara pria dan wanita yang berbeda negara atau kewarganegaraan dapat disebut sebagai perkawinan campuran. Menurut ketentuan Pasal 57 UU Perkawinan dijelaskan, "yang dimaksud dengan perkawinan campuran dalam Undang-undang ini ialah perkawinan antara dua orang yang di Indonesia tunduk pada hukum yang berlainan, karena perbedaan kewarganegaraan dan salah satu pihak berkewarganegaraan Indonesia". Perkawinan campuran yang masuk dalam lingkup UU Perkawinan yaitu hanya perkawinan yang terjadi antara 2 (dua) orang yang berbeda kewarganegaraan. Titik berat perkawinan campuran adalah adanya perbedaan kewarganegaraan, sehingga calon mempelai dengan sendirinya tunduk pada hukum yang berlainan.

Perkawinan mengakibatkan suatu ikatan hak dan kewajiban, juga menyebabkan suatu bentuk kehidupan bersama dari para pribadi yang melakukan hubungan perkawinan itu, yaitu membentuk suatu keluarga atau somah (gezin/household). ${ }^{16)}$ Salah satu akibat dari suatu perkawinan yang sah (termasuk perkawinan campuran) adalah terciptanya harta benda bersama dalam perkawinan. Harta atau kekayaan diperlukan guna memenuhi segala keperluan yang dibutuhkan dalam kehidupan berkeluarga. ${ }^{17)}$

Menurut Pasal 35 Ayat 1 dan Pasal 36 Ayat 1 UU Perkawinan, harta bersama dalam perkawinan dijelaskan sebagai berikut, “(1) Harta benda yang diperoleh selama perkawinan menjadi harta bersama, dan (1) Mengenai harta bersama, suami atau isteri dapat bertindak atas persetujuan kedua belah pihak". Sedangkan M. Yahya Harahap menyatakan bahwa pada dasarnya semua harta yang diperoleh selama ikatan perkawinan menjadi yurisdiksi harta bersama yang dikembangkan dalam proses peradilan. Berdasarkan pengembangan tersebut maka hal. 244

${ }^{16}$ Soerjono Soekanto, Hukum Adat Indonesia, (Jakarta: Raja Grafindo Persada, 2002),

${ }^{17}$ Sonny Dewi Jusiasih, Harta Benda Perkawinan Kajian terhadap Kesetaraan Hak dan Kedudukan Suami dan Istri atas Kepemilikan Harta dalam Perkawinan, (Bandung: Refika Aditama, 2015), hal. 23 
harta perkawinan yang termasuk dalam yurisdiksi harta bersama adalah sebagai berikut: ${ }^{18)}$

1. Harta yang dibeli selama dalam ikatan perkawinan berlangsung. Setiap barang yang dibeli selama dalam ikatan perkawinan menjadi yurisdiksi harta bersama. Siapa yang membeli, atas nama siapa terdaftar, dan dimana letaknya tidak menjadi persoalan.

2. Harta yang dibeli dan dibangun pasca perceraian yang dibiayai dari harta bersama. Suatu barang termasuk yurisdiksi harta bersama atau tidak ditentukan oleh asal-usul biaya pembelian atau pembangunan barang yang bersangkutan, meskipun barang itu dibeli atau dibangun pasca terjadinya perceraian.

3. Harta yang dapat dibuktikan diperoleh selama dalam ikatan perkawinan. Semua harta yang diperoleh selama ikatan perkawinan dengan sendirinya menjadi harta bersama.

4. Penghasilan harta bersama dan harta bawaan. Penghasilan yang berasal dari harta bersama menjadi yurisdiksi harta bersama, demikian pula penghasilan dari harta pribadi suami-istri juga termasuk didalamnya. Segala penghasilan pribadi suami dan istri, sepanjang terhadap penghasilan pribadi tersebut tidak terjadi pemisahan harta, maka dengan sendirinya terjadi penggabungan sebagai harta bersama. Penggabungan penghasilan pribadi suami-istri ini terjadi demi hukum, sepanjang suamiistri tidak menentukan lain dalam perjanjian kawin.

Terhadap harta bersama dalam perkawinan campuran menimbulkan hal yang sangat rumit karena melibatkan beberapa sistem hukum, yaitu hukum nasional dalam hal ini UU Perkawinan dan hukum negara lain. Apabila pelaksanaan perkawinan campuran tersebut dilangsungkan di Indonesia maka perkawinan campuran tersebut dengan segala akibatnya harus tunduk kepada hukum perkawinan di Indonesia. Harta bersama dalam perkawinan campuran sangat memungkinkan adanya percampuran harta. Percampuran harta tersebut dapat berupa benda tidak bergerak yaitu tanah.

18 Abdul Manal, Aplikasi Asas Equalitas Hak dan Kedudukan Suami Istri dalam Penjaminan Harta Bersama pada Putusan Mahkamah Agung, (Bandung: Mandar Maju, 2006), hal. 59-60 
Apabila seorang suami atau istri yang berkewarganegaraan Indonesia membeli tanah dengan hak milik sepanjang perkawinan berlangsung maka tanah tersebut akan menjadi harta bersama, sehingga tanah tersebut dengan sendirinya juga menjadi milik suami atau istri yang berkewarganegaraan asing. Oleh karena itu, pembentukan harta bersama dalam perkawinan campuran menyebabkan warga negara asing juga memiliki kewenangan dan kedudukan yang sama dengan warga negara Indonesia untuk memiliki harta bersama dalam bentuk hak milik atas tanah.

Tetapi warga negara asing tetap tidak dapat memiliki secara mutlak hak milik atas tanah karena berlaku ketentuan dalam Pasal 21 Ayat 3 UUPA yang telah dijelaskan sebelumnya. Tetapi terhadap warga negara Indonesia masih dimungkinan untuk tetap dapat memiliki hak milik atas tanah meskipun melakukan perkawinan campuran, dengan ketentuan adanya perjanjian pemisahan harta sesuai ketentuan Pasal 29 Ayat 1 UU Perkawinan, "Pada waktu atau sebelum perkawinan dilangsungkan, kedua pihak atas persetujuan bersama dapat mengadakan perjanjian tertulis yang disahkan oleh Pegawai pencatat perkawinan, setelah mana isinya berlaku juga terhadap pihak ketiga sepanjang pihak ketiga tersangkut". Di mana terhadap hak milik atas tanah tersebut merupakan harta bawaan dari suami atau istri berkewarganegaraan Indonesia, dan sebelum perkawinan campuran dilakukan telah diadakan perjanjian pemisahan harta terhadap hak milik atas tanah tersebut. Suami atau istri yang berkewarganegaraan asing pada akhirnya dapat memiliki hak milik atas tanah melalui percampuran harta, apabila dengan syarat suami atau istri tersebut pindah kewarganegaraan menjadi warga negara Indonesia. Maka ketentuan Pasal 21 Ayat 1 UUPA tetap menjadi mutlak.

\section{Pengaturan dalam UU Kewarganegaraan}

Jadi berdasarkan uraian sebelumnya, suami atau istri yang berkewarganegaraan asing harus memperhatikan status kewarganegaraannya setelah menikah dan hak atas tanah properti tersebut. Apabila suami atau istri yang berkewarganegaraan asing tersebut ingin memiliki hak milik atas atas properti tersebut, maka warga negara asing tersebut harus merubah 
kewarganegaraannya menjadi warga negara Indonesia, salah satu cara memperoleh status kewarganegaraan WNI adalah melalui perkawinan yang sah.

Berdasarkan ketentuan Undang-Undang Nomor 12 Tahun 2006 tentang Kewarganegaraan Republik Indonesia (yang selanjutnta disebut UU Kewarganegaraan). Mengenai status kewarganegaraan dalam perkawinan campuran, hal tersebut diatur di dalam Pasal 19 Ayat 1 dan 2 UU Kewarganegaraan, yang berbunyi:

“(1) Warga negara asing yang kawin secara sah dengan Warga Negara Indonesia dapat memperoleh Kewarganegaraan Republik Indonesia dengan menyampaikan pernyataan menjadi warga negara dihadapan Pejabat. (2) Pernyataan sebagaimana dimaksud pada ayat (1) dilakukan apabila yang bersangkutan sudah bertempat tinggal di wilayah negara Republik Indonesia paling singkat 5 (lima) tahun berturut-turut atau paling singkat 10 (sepuluh) tahun tidak berturut-turut, kecuali dengan perolehan kewarganegaraan tersebut mengakibatkan berkewarganegaraan ganda.

Hal ini berarti status kewarganegaraan warga negara asing yang menikah dengan warga negara Indonesia dapat memperoleh status kewarganegaraan Indonesia, selama hal tersebut tidak menyebabkan si warga negara asing memiliki kewarganegaraan ganda.

Hal ini disebabkan Indonesia menganut Asas Kewarganegaraan Tunggal, yang berarti asas yang menentukan satu kewarganegaraan bagi setiap orang. ${ }^{19)}$ Jadi, setiap warga negara hanya memiliki satu kewarganegaraan, tidak bisa memiliki kewarganegaraan ganda atau lebih dari satu. Dalam Pasal 19 Ayat 3 UU Kewarganegaraan juga menjelaskan lebih lanjut, apabila status kewarganegaraan Indonesia ditolak karena menyebabkan kewarganegaraan ganda, maka yang bersangkutan dapat diberi izin tinggal tetap sesuai dengan peraturan perundangundangan, tetapi tidak merubah status kewarganegaraan menjadi warga negara Indonesia.

${ }^{19}$ Srijanti A. et al., Pendidikan Kewarganegaraan untuk Mahasiswa, (Yogyakarta: Graha Ilmu, 2009), hal. 75 


\section{PENUTUP}

\section{A. Kesimpulan}

Dengan demikian, dapat dikatakan bahwa sesungguhnya warga negara asing tidak dapat memiliki hak atas tanah di Indonesia sesuai dengan apa yang diatur di dalam peraturan perundang-undangan. Warga negara asing hanya dimungkinkan untuk memperoleh hak pakai ataupun hak sewa atas suatu tanah dan/atau bangunan. Namun yang menjadi pengecualian disini, kepemilikan tanah oleh warga negara asing dapat dilakukan apabila seorang warga negara asing tersebut melakukan perkawinan campuran dengan orang Indonesia. Dimana yang pada akhirnya yang memiliki status pemilik harus tetap warga negara Indonesia dengan terlebih dahulu dilakukannya perjanjian pemisahan harta bersama sebelum dilangsungkannya perkawinan campuran tersebut. Pengecualian lain pula dapat dilakukan apabila seorang warga negara asing tersebut secara sah dan tidak melawan hukum merubah kewarganegaraanya menjadi warga negara Indonesia. Dimana warga negara asing tersebut akan mengemban seluruh hak dan kewajiban sebagai warga negara Indonesia, selama hal tersebut tidak menyebabkan warga negara asing tersebut memiliki kewarganegaraan ganda. Hal ini disebabkan Indonesia menganut Asas Kewarganegaraan Tunggal.

\section{B. Saran}

Semoga kedepannya regulasi mengenai perkawinan campuran atau status hak kepemilikan yang berupa objek tanah lebih diperketat, sehubungan dengan adanya modus dari warga negara asing yang melakukan perkawinan campuran hanya untuk menguasai kepemilikan tanah di Indonesia. Dengan tidak dapat dipungkirinya perkembangan ITE yang sangat maju, diharapkan juga diimbangi dengan adanya perkembangan regulasi akan status kepemilikan oleh warga negara asing, yang mana dewasa ini hal tersebut sudah menjadi fenomena sosial yang perlu dihindari. Untuk menghindari adanya "penjajahan" pihak asing, terutama pada hak kepemilikan tanah di Indonesia. 


\section{DAFTAR PUSTAKA}

\section{Buku}

Curzon, L.B.Land Law. seventh edition. (Great Britain: Pearson Education Limited, 1999).

Hadikusuma, Hilman.Hukum Perkawinan Indonesia Menurut Perundangan, Hukum Adat, Hukum Agama. Cetakan ke-3. (Bandung: Mandar Maju, 2007).

Jusiasih, Sonny Dewi.Harta Benda Perkawinan Kajian terhadap Kesetaraan Hak dan Kedudukan Suami dan Istri atas Kepemilikan Harta dalam Perkawinan. (Bandung: Refika Aditama, 2015).

Lubis, Muhammad Yamin dan Abdul Rahim Lubis.Hukum Pendaftaran Tanah.(Bandung: Mandar Maju, 2010).

Manal, Abdul.Aplikasi Asas Equalitas Hak dan Kedudukan Suami Istri dalam Penjaminan Harta Bersama pada Putusan Mahkamah Agung.(Bandung: Mandar Maju, 2006).

Masjchoen Sofwan, Sri Soedewi. Hukum Perdata: Hukum Benda, (Yogyakarta: Liberty, 2000).

Pound, Roscoe.Pengantar Filsafat Hukum. (Jakarta: Bhratara Niaga Media, 1989).

Roestamy, Martin.Konsep-Konsep Hukum Kepemilikan Properti Bagi Orang Asing (Dihubungkan dengan Hukum Pertanahan). (Bandung: Alumni, 2011).

Santoso, Urip.Hukum Agraria Dan Hak - Hak Atas Tanah. Cetakan ke-5. (Jakarta: Kencana Pranada Medoa, 2009). Media, 2015).

Soekanto, Soerjono.Teori Sosiologi Tentang Perubahan Sosial. Cetakan ke-2. (Jakarta: Ghalia Indonesia, 1984).

.Hukum Adat Indonesia. (Jakarta: Raja Grafindo Persada, 2002).

Srijanti, A., dkk., Pendidikan Kewarganegaraan untuk Mahasiswa, (Yogyakarta: Graha Ilmu, 2009).

\section{Peraturan Perundang - Undangan}

Indonesia, Undang - Undang Nomor 5 Tahun 1960 tentang Peraturan Dasar Pokok - Pokok Agraria (Lembaran Negara Republik Indonesia Tahun 1960 Nomor 104, Tambahan Lembaran Negara Republik Indonesia Nomor 2043).

, Undang - Undang Nomor 1 Tahun 1974 tentang Perkawinan (Lembaran Negara Republik Indonesia Tahun 1974 Nomor 1, Tambahan Lembaran Negara Republik Indonesia Nomor 23019). 
Undang - Undang Nomor 12 Tahun 2006 tentang Kewarganegaraan Republik Indonesia (Lembaran Negara Republik Indonesia Tahun 2006 Nomor 63, Tambahan Lembaran Negara Republik Indonesia Nomor 4634).

Peraturan Pemerintah Nomor 103 Tahun 2015 Tentang Pemilikan Rumah Tempat Tinggal atau Hunian oleh Orang Asing yang Berkedudukan Di Indonesia (Lembaran Negara Republik Indonesia Tahun 2015 Nomor 325, Tambahan Lembaran Negara Republik Indonesia Nomor 5793) Kitab Undang - Undang Hukum Perdata.

\section{Jurnal}

Idowu, Bayo. et al. "Information and Communication Technology in Nigeria The Health Sector Experience". Journal of Information Technology Impact. Volume 3 No.2 Tahun 2018.

Listyanti, Kadek Rita dan Ni Made Ari Yuliartini Griadhi. "Hak Atas Tanah Bagi Orang Asing Di Indonesia Terkait Dengan Undang-Undang No. 5 Tahun 1960”.E-Jurnal Universitas Udayana. Volume 1. Tahun 2014.

Luther, Catherine Adan Jodi L. Rightler-McDaniels. "More Trouble than the Good Lord Ever Intended: Representations of Interracial Marriage in U.S. News-Oriented Magazines". Journal of Magazine \& New Media Research. Volume 4 No. 1 Tahun 2013.

Sondakh, Jemmy. "Hak Milik atas Tanah Menurut Hukum Adat". E-Journal Universitas Sam Ratulangi. Tahun 2014.

\section{Internet:}

Anonim. "Kasus Menjerite Ungkap Modus Kepemilikan Tanah WNA di Mabar".http://www.floresa.co/2017/01/17/kasus-menjerite-ungkapmodus-kepemilikan-tanah-wna-di-mabar/ 